\title{
Pengaruh kepemimpinan dan kompensasi finansial terhadap kinerja karyawan PT Sinar Indah Perkasa Surabaya
}

\author{
Karmanto $^{1}$, Hidayat ${ }^{2}$ \\ ${ }^{1 \& 2}$ Fakultas Ekonomi dan Bisnis Universitas Wijaya Putra Surabaya \\ karmanto1506@gmail.com
}

\begin{abstract}
This study aims to examine and analyze the influence of leadership and financial compensation on employee performance. The analysis unit in this study was all employees as many as 54 people. Samples used saturated sampling technique where members of the population were used as samples. Data analysis was performed using statistics with SPSS tools. F test results F value calculated $47.702>$ F table and significance level $0.000<$ alpha 0.05 means that simultaneously the variables of leadership and financial compensation have a significant effect on employee performance variables. Results of calculations with regression analysis multiple linear on t test obtained coefficient value of 0.544 for leadership and 0.467 for financial compensation. The result is that partial leadership and financial compensation have a significant influence on employee performance.
\end{abstract}

Keywords: Leadership, financial compensation, employee performance.

\begin{abstract}
Abstrak: Penelitian ini bertujuan untuk menguji dan menganalisis pengaruh kepemimpinan dan kompensasi finansial terhadap kinerja karyawan .Unit analisis dalam penelitian ini adalah semua karyawan sebanyak 54 orang.Sampel menggunakan teknik sampling jenuh dimana anggota populasi digunakan sebagai sampel. Analisa data dilakukan dengan menggunakan statistic dengan alat bantu SPSS.Hasil uji F nilai F hitung 47,702 > F tabel dan tingkat signifikansi 0,000 <alpha 0,05 berarti secara simultan variabel kepemimpinan dan kompensasi finansial berpengaruh signifikan terhadap variabel kinerja karyawan.Hasil perhitungan dengan analisis regresi linier berganda pada Uji t diperoleh nilai koefisien 0,544 untuk kepemimpinan dan 0,467 untuk kompensasi finansial .Hasilnya diketahui bahwa secara parsial kepemimpinan dan kompensasi finansial memiliki pengaruh signifikan terhadap kinerja karyawan.
\end{abstract}

Kata Kunci: Kepemimpinan, kompensasi finansial, kinerja karyawan. 


\section{PENDAHULUAN}

Setiap organisasi pemerintah maupun swasta akan fokus pada orientasi pengembangan usaha jangka panjang. Organisasi saat ini bukan lagi dipandang hanya kumpulan orang yang secara statis sebagai suatu sistem yang kompleks, yang didalamnya terkandung subsistem yang kompleks yang saling berinteraksi dan berhubungan serta secara dinamis bergerak ke arah pencapaian tujuan yang disepakati bersama, sehingga yang berperan besar dalam mengkoordinasikan kegiatan-kegiatan dalam organisasi disebut manajemen Salah satu upaya untuk mencapai tujuan organisasi atau perusahaan dibutuhkan kinerja karyawan sesuai dengan standar dan norma organisasi. Jika kinerja sumber daya manusia bagus, maka tujuan dan misi organisasi juga akan bagus, begitu juga sebaliknya.

Kemajuan suatu perusahaan atau organisasi tentunya didukung oleh kinerja karyawan. Seseorang dapat dikatakan mempunyai kinerja yang baik, manakala mereka dapat melaksanakan pekerjaan dengan baik, artinya mencapai sasaran dengan atau menurut standar yang ditentukan dengan penilaian kinerja, dengan kata lain akan mendorong karyawan untuk bersaing memperoleh penghargaan, bonus, atau dipromosikan jabatan yang lebih baik. Sumber daya manusia yang dimiliki suatu perusahaan merupakan aset berharga yang menjadi faktor penentu keberhasilan perusahaan tersebut. Tercapai tidaknya tujuan perusahaan tidak hanya dinilai dari perusahaan tersebut telah memiliki karyawan-karyawan yang mempunyai kemampuan yang tinggi saja, namun juga dipengaruhi oleh hal lain yang dapat mendorong timbulnya semangat untuk bekerja dengan baik.

Faktor-faktor yang mempengaruhi kinerja, antara lain: kepemimpinan, kompensasi finansial, dan masih banyak lainnya. Peran pemimpin dalam segala situasi organisasi merupakan suatu faktor yang sangat strategis. Peran seorang pemimpin sangat besar terhadap baik tidaknya kinerja seorang karyawan pada suatu perusahaan. Veithzal Rivai (2013) mengemukakan bahwa "Kepemimpinan adalah suatu perilaku dengan tujuan tertentu untuk mempengaruhi aktivitas para anggota kelompok untuk mencapai tujuan bersama yang dirancang untuk memberikan manfaat individu dan organisasi, sehingga dalam suatu organisasi kepemimpinan merupakan faktor yang sangat penting dalam menentukan pencapaian tujuan yang telah ditetapkan oleh organisasi”.

Karyawan pada PT. Sinar Indah Perkasa merasa ada kecenderungan terhadap seorang pemimpin perusahaan yang masih belum memimpin dengan baik. Hal ini ditujukan oleh seorang pemimpin yang kurang mempengaruhi, mendorong, menuntun, dan menggerakkan bawahaanya. Sehingga karyawan merasa kurangnya perhatian dari seorang pemimpin. Selain dari sisi kepemimpinan yang dapat mempengaruhi baik tidaknya kinerja seorang karyawan, namun juga dari sisi perusahaan memiliki pengaruh yang cukup besar. Perusahaan harus dapat memberikan timbal balik atas kinerja karyawan-karyawannya. Pada dasarnya manusia bekerja untuk mendapatkan imbalan 
atas pekerjaan yang telah dilakukannya Imbalan bagi karyawan merupakan salah satu faktor kunci untuk mencapai kinerja. Pemberian kompensasi merupakan salah satu tugas dari fungsi personalia yang paling kompleks dan juga merupakan salah satu aspek yang paling berarti baik bagi karyawan maupun bagi organisasi. Kompensasi yang diberikan sesuai dengan jenis pekerjaan dan golongan kerja karyawan dalam bekerja. Hal ini didukung oleh pendapat Saifuddin (2011:102) bahwa pemberian kompensasi atau balas jasa dapat diberikan atas dasar kinerja individu, kinerja kelompok, maupun kinerja perusahaan secara keseluruhan.Oleh karena itu, faktor-faktor tersebut harus diperhatikan agar kinerja dapat ditingkatkan. Kompensasi mencakup semua jenis pembayaran baik secara langsung maupun tidak langsung, berbentuk materil atau uang maupun penghargaan yang diberikan perusahaan kepada pekerja atau buruhnya.

Penelitian ini mengambil satu jenis kompensasi yakni pembayaran langsung berbentuk finansial. Kompensasi finansial berupa gaji, bonus, komisi, program perlindungan.Kompensasi yang berwujud finansial kemudian menjadi sesuatu yang dianggap penting bagi karyawan sebagai individu, karena besarnya jumlah finansial ini masih sering dianggap dapat mencerminkan ukuran nilai karya mereka diantara para karyawan itu sendiri,keluarga, dan masyarakat.Akhirnya timbul persepsi bahwa besarnya kompensasi adalah lebih dari sekedar uang dalam jumlah tertentu yang dapat dibelanjakan. Pemberian kompensasi finansial yang sesuai dengan kinerja karyawan diharapkan bahwa karyawan memiliki komitmen sehingga karyawan tersebut akan meningkatkan kinerjanya demi keberhasilan dan kemajuan perusahaan dalam mencapai tujuannya. Disisi lain, kompensasi yang diberikan kepada karyawan menurun.Walaupun kompensasi yang diberikan PT.Sinar Indah Perkasa telah dilaksanakan sesuai peraturan yang telah ditetapkan dan besarnya nilai kompensasi yang diterima karyawan sudah diketahui, ada kecenderungan bahwa kompensasi yang diterima belum memuaskan. Kinerja merupakan suatu hasil kerja yang dihasilkan karyawan.

Menurut Mangkunegara, (2011:75) kinerja adalah hasil kerja secara kualitas dan kuantitas yang dicapai oleh seorang karyawan dalam melaksanakan tugasnya sesuai dengan tanggung jawab yang diberikan kepadanya. Kinerja karyawan dalam menjalankan fungsinya juga tidak berdiri sendiri tapi berhubungan dengan kepuasaan kerja dan tingkat imbalan, dipengaruhi oleh keterampilan kemampuan dan sifat-sifat individu. PT.Sinar Indah Perkasa merupakan distributor PT.Semen Indonesia, khususnya PT. Semen Gresik yang menyuplai kebutuhan semen seluruh pulau Jawa, dengan terget volume semen Portland Tipe 1 (OPC) sebesar 2 Juta ton per tahun. Agar mampu memberikan pelayanan yang baik, diperlukan kepemimpinan yang baik dan dukungan kepada karyawan untuk berkontribusi terhadap pencapaian tujuan PT Sinar Indah Perkasa. Dari uraian masalah diatas yang membahas masalah kepemimpinan dan kompensasi finansial guna mengembangkan tingkat kinerja karyawan yang lebih baik. 


\title{
TINJAUAN TEORITIS
}

\author{
Kinerja Karyawan
}

Pengertian Kinerja yang dikemukakan oleh Anwar Prabu Mangkunegara (2011:75) yaitu, "Kinerja adalah hasil kerja secara kuantitas dan kualitas yang dicapai oleh seorang pegawai dalam melaksanakan tugas kerjanya sesuai dengan tanggung jawab yang diberikan kepadanya". Kemudian menurut Wibowo (20011:7), "Kinerja berasal dari pengertian performance, ada pula yang memberikan pengertian performance sebagai hasil kerja atau prestasi kerja, namun sebenarnya kinerja mempunyai makna yang lebih luas, bukan hanya hasil kerja, tetapi termasuk bagaimana proses pekerjaan berlangsung". Selanjutnya, definisi kinerja dikemukakan oleh Dessler dalam Edy (2011:5) bahwa, "Kinerja pegawai adalah prestasi aktual pegawai dibandingkan dengan prestasi yang diharapkan dari pegawai".

Menurut Sedarmayanti (2011:260) mengungkapkan bahwa, "Kinerja merupakan terjemahan dari performance yang berarti hasil kerja seorang pekerja, sebuah proses manajemen atau suatu organisasi secara keseluruhan, dimana hasil kerja tersebut harus dapat ditunjukkan buktinya secara konkrit dan dapat diukur (dibandingkan dengan standar yang telah ditentukan). Marwansyah (2014) ada tiga level kinerja yaitu:

1 Kinerja organisasi, merupakan pencapaian hasil (outcome) pada level atau unit analisis organisasi terkait dengan tujuan organisasi, rancangan organisasi, dan manajemen organisasi.

2 Kinerja proses, merupakan kinerja pada proses tahapan dalam menghasilkan produk atau layanan yang dipengaruhi oleh tujuan proses, rancangan proses, dan manajemen proses;

3 Kinerja individu/pekerjaan, merupakan pecapaian efektivitas pada tingkah pegawai atau pekerjaan yang dipengaruhi oleh tujuan pekerjaan, rancangan pekerjaan, dan manajemen pekerjaan serta karakteristik individu. Pendapat lain menurut Marwansyah (2014) mengatakan bahwa kinerja adalah pencapaian atau prestasi seseorang berkenaan dengan tugas-tugas yang dibebankan padanya.

Beberapa faktor yang mempengaruhi kinerja karyawan menurut Mangkunegara (2012:14) diantaranya adalah; faktor individual yang terdiri dari kemampuan,latar belakang dan demografi, faktor psikologis yang terdiri dari persepsi,tingkah laku, kepribadian, pembelajaran, dan motivasi, dan faktor yang lain adalah faktor organisasi yang terdiri dari sumberdaya, kepemimpinan, kompensasi, struktur, dan job design.

Selain itu, terdapat beberapa indikator yang diyakini dapat menjadi pengukur dari kinerja karyawan (Risambessy et al., 2012), diantaranya adalah; Kualitas (quality) merupakan hasil pelaksanaan kegiatan pelayanan dicapai dengan mengutamakan kualitas dan ketepatan. Kuantitas (quantity) merupakan hasil dari jasa dilakukan dengan tanggung jawab yang diberikan sesuai dengan waktu kerja melebihi waktu kerja. Ketepatan waktu 
(time lines) adalah panjang dari suatu kegiatan diselesaikan cepat dan influenceive. Efektivitas biaya (cost effectiveness) yang besarnya lain yang berpengaruh dan efisien sumber daya organisasi. Perlu pengawasan (need for supervision) adalah kemampuan karyawan untuk melakukan fungsi pekerjaan yang membutuhkan pengawasan supervisor untuk mencegah tindakan yang tidak diinginkan.

\section{Kepemimpinan}

Kepemimpinan merupakan faktor yang menentukan dalam suatu perusahaan. Berhasil atau gagalnya perusahaan dalam mencapai suatu tujuan dipengaruhi oleh cara seorang pemimpin. Sosok pemimpin dalam perusahaan dapat menjadi efektif apabila pemimpin tersebut mampu mengelola perusahaannya dan mempengaruhi perilaku bawahan agar mau bekerja sama dalam mencapai tujuan perusahaan. Drath et al (2015:3) menyatakan bahwa: "Kepemimpinan adalah proses untuk memahami apa yang dilakukan orang secara bersama-sama, sehingga mereka memahami dan mau melakukannya". Veithzal Rivai (2013:3) mengemukakan bahwa: "Kepemimpinan adalah suatu perilaku dengan tujuan tertentu untuk mempengaruhi aktivitas para anggota kelompok untuk mencapai tujuan bersama yang dirancang untuk memberikan manfaat individu dan organisasi, sehingga dalam suatu organisasi kepemimpinan merupakan faktor yang sangat penting dalam menentukan pencapaian tujuan yang telah ditetapkan oleh organisasi”.

Cepi Priatna (2015:30) berpendapat: "Kepemimpinan adalah peningkatan pengaruh sedikit demi sedikit berada diatas kepatuhan mekanis terhadap pengarahan-pengarahan rutin organisasi". Berdasarkan semua pengertian yang telah dikemukakan para ahli diatas, maka dapat diambil kesimpulan bahwa kepemimpinan adalah proses dan perilaku seorang pemimpin dalam mempengaruhi perilaku dan mendayagunakan para bawahannya agar mau bekerja sama dalam melaksanakan tugas dan tanggung jawab untuk mencapai tujuan perusahaan. Indikator kepemimpinan Menurut Wahjosumidjo (Wijayanti, 2012), secara garis besar indikator kepemimpinan adalah sebagai berikut:

a. Bersifat adil, dalam kegiatan suatu organisasi, rasa kebersamaan diantara para anggota adalah mutlak, sebab rasa kebersamaan pada hakikatnya merupakan pencerminan dari pada kesepakatan antara para bawahan maupun antara pemimpin dengan bawahan dalam mencapai tujuan organisasi

b. Memberi sugesti, sugesti biasanya disebut sebagai saran atau anjuran. Dalam rangka kepemimpinan, sugesti merupakan pengaruh dan sebagainya, yang mampu menggerakkan hati orang lain dan sugesti mempunyai peranan yang sangat penting di dalam memelihara dan membina harga diri serta rasa pengabdian, partisipasi, dan rasa kebersamaan diantara parabawahan.

c. Mendukung tujuan Tercapainya tujuan organisasi tidak secara otomatis terbentuk, melainkan harus didukung oleh adanya kepemimpinan. Oleh karena itu, agar setiap organisasi dapat efektif dalam arti mampu mencapai tujuan yang telah ditetapkan, 
maka setiap tujuan yang ingin dicapai perlu disesuaikan dengan keadaan organisasi serta memungkinkan para bawahan untuk bekerja sama.

d. Katalisator Seorang pemimpin dikatakan berperan sebagai katalisator, apabila pemimpin itu selalu dapat meningkatkan segala sumber daya manusia yang ada, berusaha memberikan reaksi yang menimbulkan semangat dan daya kerja cepat semaksimal mungkin.

e. Menciptakan rasa aman Setiap pemimpin berkewajiban menciptakan rasa aman bagi para bawahannya. Dan ini hanya dapat dilaksanakan apabila setiap pemimpin mampu memelihara hal-hal yang positif, sikap optimisme di dalam menghadapi segala permasalahan, sehingga dalam melaksanakan tugas-tugasnya, bawahan merasa aman, bebas dari segala perasaan gelisah, kekhawatiran, merasa memperoleh jaminan keamanan dari pimpinan.

\section{Kompensasi Finansial}

Masalah kompensasi sensitif karena menjadi pendorong seseorang untuk bekerja juga berpengaruh terhadap moral dan disiplin tenaga kerja. Oleh karena itu, setiap perusahaan atau organisasi manapun seharusnya dapat memberikan kompensasi yang seimbang dengan beban kerja yang dipikul tenaga kerja. Berikut ini akan dikemukakan beberapa definisi dari kompensasi. Menurut Hasibuan (2012:118) mendefinisikan, "Kompensasi adalah semua pendapatan yang berbentuk uang, barang langsung atau tidak langsung yang diterima karyawan sebagai imbalan atas jasa yang diberikan kepada perusahaan". Sedangkan, menurut Rivai (2011:357) menjelaskan bahwa, "Kompensasi merupakan sesuatu yang karyawan dapatkan sebagai pengganti kontribusi jasa mereka pada perusahaan". Sistem imbalan bisa mencakup gaji, penghasilan, uang pensiun, uang liburan, promosi ke posisi yang lebih tinggi. Juga berupa asuransi keselamatan kerja, transfer secara horizontal untuk mendapat posisi yang lebih menantang atau ke posisi utama untuk pertumbuhan dan pengembangan berikutnya, serta berbagai macam bentuk pelayanan. Jadi berdasarkan beberapa pengertian di atas secara umum dapat dikatakan bahwa kompensasi itu merupakan balas jasa yang diterima oleh karyawan sehubungan dengan pengorbanan yang telah diberikan kepada perusahaan Pemberian kompensasi ini bisa diberikan langsung berupa uang maupun tidak langsung berupa uang dari perusahaan ke karyawannya.

Menurut Rivai (2011: 357) kompensasi finansial langsung terdiri dari beberapa hal yaitu sebagai berikut:

a. Gaji Gaji adalah balas jasa dalam bentuk uang yang diterima karyawan sebagai konsekuensi dari kedudukannya sebagai seorang karyawan yang memberikan sumbangan tenaga dan pikiran dalam mencapai tujuan perusahaan atau dapat juga dikatakan sebagai bayaran tetap yang diterima seseorang dari keanggotaannya dalam sebuah perusahaan. 
b. Bonus Bonus adalah pembayaran sekaligus yang diberikan karena memenuhi sasaran kinerja atau uang yang dibayar sebagai balas jasa atas hasil pekerjaan yang telah dilaksanakan apabila melebihi target. Bonus juga merupakan kompensasi tambahan yang diberikan kepada seorang karyawan yag nilainya di atas gaji normalnya. Bonus juga bisa digunakan sebagai penghargaan terhadap pencapaian tujuan-tujuan spesifik yang ditetapkan oleh perusahaan, atau untuk dedikasinya kepada perusahaan.

c. Insentif Insentif merupakan imbalan langsung yang dibayarkan kepada karyawan karena kinerjanya melebihi standar yang ditentukan. Insentif merupakan bentuk lain dari upah langsung di luar upah dan gaji yang merupakan kompensasi tetap, yang biasa disebut kompensasi berdasarkan kinerja (pay for performance plan). Insentif adalah variabel penghargaan yang diberikan kepada individu dalam suatu kelompok, yang diketahui berdasarkan perbedaan dalam mencapai hasil kerja. Ini di rancang untuk memberikan motivasi karyawan berusaha meningkatkan produktivitas kerjanya.

Sedangkan kompensasi tidak langsung menurut Hasibuan (2012: 118) adalah kompensasi yang diterima oleh karyawan yang tidak mempunyai hubungan secara langsung dengan pekerjaannya antara lain, asuransi kesehatan, bantuan pendidikan, pembayaran selama cuti atau sakit. Jadi dapat disimpulkan bahwa perusahaan harus memperhatikan pemberian kompensasi finansial dengan sesuai dan adil, karena kompensasi finansial sangat mempengaruhi kinerja karyawan. Semakin tinggi kompensasi finansial yang diberikan oleh perusahaan, maka semakin meningkat pula kinerja karyawannya. Sebaliknya, jika perusahaan memberikan kompensasi, maka kinerja karyawannya juga akan menurun.

\section{METODE PENELITIAN}

Metode penelitian yang digunakan pada studi ini adalah metode kuantitatif yang menitik beratkan pada pengujian hipotesis (Sugiyono, 2012). Populasi dalam penelitian ini adalah seluruh karyawan PT Sinar Indah Perkasa yang berjumlah 55 orang, sampel yang digunakan dalam penelitian ini adalah seluruh karyawan PT Sinar Indah Perkasa berjumlah 54 orang.

Teknik pengumpulan data mengggunakan angket atau kuesioner melalui pertanyaan atau pernyataan yang disusun peneliti untuk mengetahui pendapat / persepsi responden penelitian tentang suatu variabel yang diteliti (Juliandi dkk., 2015:69). Angket yaitu sejumlah pertanyaan yang berkaitan dengan permasalahan dan disebarkan untuk diisi jawabannya oleh karyawan dan kemudian disajikan dalam bentuk tabulasi pada proses pengolahan data. Metode analisis regresi linear berganda digunakan untuk mengetahui berapa besar pengaruh kepemimpinan (X1) dan kompensasi finansial (X2) terhadap kinerja karyawan (Y) pada PT Sinar Indah Perkasa. Untuk mempeoleh hasil yang lebih terarah, peneliti menggunakan bantuan SPSS. Persamaan model Regresi Linear Berganda yang digunakan adalah sebagai berikut: 


$$
\mathrm{Y}=\mathrm{a}+\beta+\beta 1 \mathrm{X} 1+\beta 2 \mathrm{X} 2+\mathrm{e}
$$

Keterangan:

$\begin{array}{ll}\mathrm{Y} & \text { : Kinerja Karyawan } \\ \mathrm{a} & \text { : Konstanta } \beta 1, \beta 2: \text { Koefisien Regresi } \\ \mathrm{X} 1 & \text { : Variabel kompensasi finansial } \\ \mathrm{X} 2 & \text { : Variabel kepemimpinan } \\ \mathrm{e} & \text { : Standard error }\end{array}$

\section{HASIL DAN PEMBAHASAN}

\section{Hasil Uji Regresi Linier Berganda}

Analisis regresi digunakan untuk mengetahui sejauh mana hubungan antara variabel bebas terhadap variabel terikat. Berdasarkan analisis regresi dengan menggunakan SPSS diperoleh hasil sebagai berikut: Dari hasil pengujian regresi linier berganda terdapat persamaan yang menunjukkan koefisien regresi dari kedua variabel bebas $(\beta 1, \beta 2)$ bertanda positif $(+)$ hal ini berarti bahwa bila variabel kepemimpinan dan kompensasi finansial terpenuhi mengakibatkan kinerja karyawan akan semakin meningkat, dan sebaliknya jika bertanda negatif (-) hal ini berarti bahwa bila variabel kepemimpinan dan kompensasi finansial tidak terpenuhi akan mengakibatkan kinerja karyawan akan menurun. Dari persamaan tersebut dapat dijelaskan bahwa:

a. Apabila nilai variabel yang terdiri dari kepemimpinan dan kompensasi finansial mempunyai nilai nol, maka variabel kinerja karyawan akan tetap sebesar 4,270, karena nilai konstanta menunjukkan nilai sebesar 4,270.

b. Nilai koefisien kepemimpinan (X1) sebesar 0,544(54,4\%) menunjukkan bahwa variabel kepemimpinan (X1) berpengaruh positif terhadap kinerja karyawan.

c. Nilai koefisien kompensasi finansial (X2) sebesar 0,467 (46,7\%) menunjukkan bahwa variabel kompensasi finansial (X2) berpengaruh positif terhadap kinerja karyawan.

\section{Pengujian Pengujian Hipotesis Secara Simultan dan Parsial}

Diketahui bahwa kepemimpinan (X1), serta kompensasi finansial (X2) secara bersama-sama (simultan) berpengaruh signifikan terhadap variabel dependen yaitu kinerja karyawan (Y).Hal ini dibuktikan dengan nilai signifikan Fhitung 47,702 lebih besar dari Ftabel 3,18 dan tingkat signifikansi 0.000 lebih kecil dari alpha 0.05.

Diketahui bahwa variabel kepemimpinan (X1) berpengaruh signifikan terhadap kinerja karyawan (Y). Hal ini dapat dibuktikan dengan hasil dari t hitung sebesar 5,159 lebih besar dari t tabel sebesar 2,007, dengan tingkat signifikansi lebih kecil dari 0.05.Maka dapat disimpulkan bahwa variabel kepemimpinan berpengaruh signifikan terhadap variabel kinerja karyawan secara parsial.Nilai $t$ hitung untuk variabel 
kompensasi finansial sebesar 3,102 lebih besar dari t tabel sebesar 2,007, dengan tingkat signifikansi lebih kecil dari 0.05. Maka dapat disimpulkan bahwa variabel kompensasi finansial berpengaruh signifikan terhadap variabel kinerja karyawan secara parsial.

\section{Analisa Koefisien Determinasi Berganda}

Hasil pengukuran koefisien korelasi berganda penelitian ini menujukkan R sebesar 0.807 menunjukkan bahwa hubungan korelasi antara kinerja karyawan dengan variabel kepemimpinan dan kompensasi finansial adalah kuat, karena nilai $\mathrm{R}$ lebih dari 0.5 maka dapat dikatakan berkorelasi kuat. Dari perhitungan koefisien determinasi berganda dengan bantuan SPSS, diketahui bahwa nilai koefisien determinasi berganda R Square adalah 0.652 atau sebesar $65,2 \%$. Nilai ini menunjukkan kinerja karyawan dipengaruhi oleh variabel kepemimpinan dan kompensasi finansial, sisanya sebesar 34,8\% dipengaruhi oleh variabel lain yang tidak diteliti dalam penelitian ini.

\section{PEMBAHASAN}

Penelitian ini bertujuan untuk menguji Pengaruh Kepemimpinan dan Kompensasi Finansial terhadap Kinerja Karyawan PT Sinar Indah Perkasa Surabaya. Hasil penelitian menunjukkan bahwa variabel kepemimpinan (X1) berpengaruh signifikan terhadap kinerja karyawan (Y) dengan t hitung sebesar 5,159 lebih besar dari t tabel sebesar 2,00758 , dengan tingkat signifikansi lebih kecil dari 0.05 itu artinya bahwa hipotesis ke1 dalam penelitian ini terbukti kebenarannya atau dapat di terima.

Hasil penelitian ini mendukung hipotesis kedua yaitu variabel Kompensasi Finansial (X1) berpengaruh terhadap Kinerja Karyawan (Y) pada karyawan PT Sinar Indah PerkasaSurabaya. Nilai t hitung 3,102 yang lebih besar dari ttabel 2,007 dengan nilai signifikansi sebesar 0,000 lebih kecil dari 0,05 $(0,000<0,05)$, mengindikasikan bahwa Kompensasi Finansial berpengaruh signifikan terhadap Kinerja Karyawan.Dari hasil tersebut maka hipotesis ke-2 dalam penelitian ini terbukti kebenarannya.

Kompensasi finansial merupakan salah satu dari beberapa upaya yang dilakukan PT Sinar Indah Perkasa Surabaya dalam meningkatkan Kinerja Karyawan. Kepemimpinan yang baikdan kompensasi finansial yang sesuai sangat penting untuk diperhatikan karena berpengaruh signifikan terhadap kinerja karyawan dan demi tercapainya tujuan perusahaan. hal ini dibuktikan dari hasil penelitian yang menunjukkan bahwa nilai Fhitung 47,702 lebih besar dari Ftabel 3,18 dan tingkat signifikansi 0.000 lebih kecil dari alpha 0.05 , yang berarti secara keseluruhan variabel kepemimpinan dan kompensasi finansial berpengaruh signifikan terhadap variabel terikat yaitu kinerja karyawan dan hipotesis ke 3 dalam penelitian ini terbukti kebenarannya.

Hasil perhitungan menggunakan analisis regresi linier berganda pada uji t, diperoleh nilai koefisien regresi untuk masing-masing variabel bebas adalah 0,544 untuk 
kepemimpinan (X1), dan 0,467 untuk kompensasi finansial (X2). Nilai koefisien regresi yang positif menunjukkan bahwa pengaruh dari masing-masing variabel bebas adalah positif.

\section{KESIMPULAN}

Berdasarkan hasil penelitian seperti yang telah diuraikan sebelumnya, maka dapat ditarik kesimpulan bahwa tanggapan responden dari hasil analisis deskriptif mengenai gambaran kepemimpinan yang ada pada PT Sinar Indah Perkasa terhadap sebagian besar menjawab baik,artinya mayoritas karyawan pada PT Sinar Indah Perkasa menilai kepemimpinan yang ada di perusahaan tersebut sudah cukup baik. Tanggapan responden dari hasil analisis deskriptif menngenai gambaran kompensasi finansial yang ada pada PT Sinar Indah Perkasa sebagian besar menjawab baik. Artinya pemberian kompensasi finansial terhadap karyawan PT Sinar Indah Perkasa sudah jelas dirasakan oleh mayoritas karyawannya. Tanggapan responden dari hasil analisis deskriptif mengenai gambaran kinerja karyawan PT. Sinar Indah Perkasa terhadap variabel kepemimpinan (X1) sebagian besar menjawab baik. Artinya mayoritas karyawan PT Sinar Indah Perkasa memiliki kinerja yang baik. Dari hasil Uji t yang telah dilakukan menunjukkan bahwa variabel kepemimpinan dan kompensasi finansial secara parsial berpengaruh signifikan terhadap kinerja karyawan Sedangkan hasil Uji F telah dilakukan menunjukkan bahwa variabel kinerja karyawan (X1), serta kompensasi finansial (X2) secara bersama-sama (simultan) berpengaruh signifikan terhadap kinerja karyawan (Y).

\section{DAFTAR PUSTAKA}

Hasibuan, M. S. P. (2011). Manajemen Sumber Daya Manusia Edisi Revisi. Jakarta: Bumi Aksara.

Ima, (2013). Kompensasi. https://hylmapratiwi.wordpress.com/2013/10/20/kompensasi/ (online akses, 28 September 2015).

Juliningrum E, \& Sudiro, A. (2013). Pengaruh Kompensasi, Budaya Organisasi, terhadap Motivasi Kerja dan Kinerja Pegawai. Jurnal Aplikasi Manajemen, 11(4), 666-676.

Kadarisman. (2012). Manajemen Kompensas Edisi Pertama. Jakarta: PT Raja Grafindo Persada.

Mangkunegara. (2013). Manajemen Sumber Daya Manusia Perusahaan. Bandung: PT Remaja Rosdakarya.

Munawir, M. T, dan Shabri. (2014). Pengaruh Gaya Kepemimpinan, Motivasi, Struktur Organisasi, dan Kompensasi terhadap Kinerja Karyawan serta Dampaknya pada Kinerja Program Pascasarjana Universitas Syiah Kuala. Jurnal Manajemen Pascasarjana Universitas Syiah Kuala, 3(1), 27-36. 
IMKA Implementasi Manajemen \& Kewirausahaan - April, Vol. 1, No. 1, 74-84, 2021

Nawawi, H., Hadari. (2011). Manajemen Sumber Daya Manusia Untuk Bisnis yang Kompetitif. Yogyakarta: Gadjah Mada University Press

Usman, H. (2011). Manajemen: teori, praktik, dan riset pendidikan Edisi Ketiga. Jakarta: Bumi Aksara.

Santoso, S. (2012). Panduan Lengkap SPSS Versi 20. Jakarta: PT Elex Media Komputindo.

Slamet. R. (2011). Pengaruh Kompensasi Finansial, Gaya Kepemimpinan, danMotivasi Kerja Terhadap Kinerja Karyawan pada Perusahaan Mnufaktur di Jawa timur. Manajemen dan Kewirausahaan, 1(13), 40-45.

Sugiyono. (2012). Metode Penelitian Kuantitatif, Kualitatif dan R\&D. Bandung: Alfabeta

Tongo, Y. (2014). Pengaruh Gaya Kepemimpinan Dan Disiplin Kerja Terhadap Kinerja Anggota Detasemen A Pelopo Satuan Brigade Mobil Kepolisian Daerah Sulawesi Utara. Jurnal Riset Bisnis dan Manajemen, 2(4).103-117

Wibowo. (2011). Manajemen Kinerja Edisi Ketiga. Jakarta: PT. Raja Grafindo Persada. 